\title{
Sistem Pendukung Keputusan Penyeleksian Colour Guard Pada Marching Band Ginada Dengan Menggunakan Metode Vikor Dan Borda
}

\author{
Nurjannah $^{1 *}$, Dito Putro Utomo ${ }^{1}$ \\ Universitas Budidarma, Jl. Sisingamangaraja XII No.338, Siti Rejo I, Medan Kota, Indonesia \\ n047577@gmail.com ${ }^{1}$,ditoputro12@gmail.com ${ }^{2}$
}

\begin{abstract}
Abstrak-Sistem pedukung keputusan untuk penyeleksian colour guard dengan metode VIKOR dan Borda. Telah dibuat sebagai alat untuk menyeleksi colour guard pada SMA TELADAN Sei Rampah. Kriteria yang digunan dalam sistem pendukung keputusan penyeleksian colour guard adalah: tinggi badan, berat badan, kelincahan, stamina, dan bahasa tubuh. Kegiatan penyeleksian colour guard merupakan kegiatan rutin tiap tahunnya, maka dengan ini pelatih marching band GINADA Sei Rampah melakukan penyeleksian untuk menyeleksi anggota tetap pada marching band. Sistem Pendukung Keputusan disuatu organisasi dapat dipandang penting dal am menunjang sarana kelancaran aktifitas dan tercapainya suatu tujuan organisasi. SPK dapat hadir dalam berbagai bentuk, mulai dari bentuk sederhana berupa pengolahan data hingga bentuk aplikasi yang kompleks, dan juga dapat dimanfaatkan untuk mempercepat dan meningkatakan kualitas proses pembuatan keputusan disutau organisasi.
\end{abstract}

Kata kunci: Sistem Pendukung Keputusan, VIKOR Borda, Kriteria Penyeleksian.

Abstract-Decision support system for selecting color guard with VIKOR and Borda methods. It has been made as a tool to select color guard at the Sei Rampah High School. The criteria used in the decision support system for color guard selection are: height, weight, agility, stamina, and body language. Color guard selection activities are a routine activity every year, so GINADA marching band coach Sei Rampah hereby selects to select permanent members in the marching band. Decision Support System in an organization can be seen as important in supporting the smooth running of activities and achieving an organizational goal. SPK can come in various forms, ranging from simple forms of data processing to complex application forms, and can also be used to accelerate and improve the quality of the decision-making process in the organization.

Keywords: Decision Support System, VIKOR, Borda, Selection Criteria.

PENDAHULUAN

Secara etimologi, kata Marching Band sampai saat ini belum memiliki padanan kata dalam bahasa Indonesia. Asal-usulnya dari benua Eropa dan minim kosakata Indonesia. Sehingga tidak heran jika semua kata-kata yang berhubungan dengan marching band, baik dari nama-nama peralatan dan personilnya banyak menggunakan atau diserap dari bahasa Inggris. Dalam kesatuan Marching Band terdiri dari lima divisi, yaitu: Percussion, Horn, Gitapati, Mayoret dan Colour guard. Marching Band diartikan sebagai kegiatan seni music atau musical activity. Marching Band digunakan dalam perayaan, seperti: Parade MTQ, Lomba, Upacara 17 Agustus, dan jika mendapat undangan panggilan acara yang diperlukan.

Colour guard sebagai petugas yang membawa bendera bertiang (flags) untuk menarik seluruh perhatian penonton dan seraya seluruh pemain lain memainkan alatnya. Colour guard menari dengan melakukan atraksi dengan benderanya. Dalam pertandingan berskala nasional, colour guard bukan hanya dilengkapi dengan bendera saja, tapi juga diberi properti lain seperti kipas, bunga, topeng, dan lainnya. Colour guard yang memiliki tugas untuk menarik perhatian penonton, sepeti biasanya posisi CG diisi oleh wanita. Namun perkembangan sampai saat ini tidak terbatas untuk pria juga.

Marching band Ginada SMA Teladan Sei Rampahlahir pada tahun 1994, Marching band tersebut sudah mengikuti beberapa kejuaraan, antara lain:Pada tahun 2014 di Akpar extravaganza, tahun 2016 Raja Musik Marching Band Competition, tahun 2017 Istana Music Pearl Competition dan lainnya. Dalam kejuaraan tersebut juga diadakan kejuaran contest colour guard, drum battle, dan lainnya. Untuk itu di butuhkan siswa-siswi yang memiliki bakat untuk menjadi anggota colour guard, maka dari itu diperlukan adanya penyeleksian sebelum di tentukan menjadi anggota marching band yang salah satu divisi yaitu colour guard. Sebelumnya siswa-siswi akan diseleksi pada bagian Peraturan Baris Berbaris (PBB) dan kemudian tahapan seleksi berikutnya adalah seleksi alat. Dimana sebelumnya mereka harus mencoba beberapa alat yang telah diminati dan juga harus mampu menguasai alat tersebut. Jika tidak termasuk dalam kategori kriteria tersebut, maka akan gugur atau gagal untuk menjadi anggota marching band.

Dalam penyeleksian colour guard pada marching band GINADA beberapa hal yang menjadi permasalahan antara lain yaitu penyeleksian secara subjektif dan objektif. Subjektif yaitu penyeleksian yang didasari dimana seseorang akan berpikir secara relatif dengan hasil yang menduga, dan menggunakan perasaan, walaupun berdasarkan kriteria yang ada, sedangkan objektif yaitu penyeleksian yang didasari sikap yang harus menjunjung tinggi seseorang yang berdasarkan pandangan terhadap suatu masalah. Oleh karena itu, dibutuhkan suatu sistem pendukung keputusan dimana penyeleksian yang dilakukan secara

Sistem Pendukung Keputusan Penyeleksian Colour Guard Pada Marching Band Ginada Dengan Menggunakan 
subjektif dan objektif.

Sistem Pendukung Keputusan merupakan sistem informasi interaktif yang menyediakan informasi, pemodelan, dan pemanipulasi data. Sistem pendukung keputusan digunakan untuk membantu pengambilan keputusan dalam situasi semiterstruktur dan situasi yang tidak terstruktur, yang mana tidak seorang pun tahu secara tepat bagaimana keputusan yang harusnya di rancang[1].

Metode VIKOR merupakan penentuan ranking dari sampel-sampel yang sudah ada dengan melihat hasil dari nilai utilitas, regres dan jarak solusi sebagai alternatif terbaik dari setiap sampel dengan pembobotan kriteria dari metode Analysis Hierarchy Proses. Tujuan menggunakan metode VIKOR pada penyeleksian colour guard pada marching band GINADA dapat digunakan untuk membantu serta menentukan rekomendasi penerima colour guard dengan mempertimbangkan bebagai kriteria yang sudah ditentukan. Pada metode VIKOR masing-masing bobot yang diberikan telah menunjukkan hasil perengkingan yang sama, sehingga dapat dijadikan sebagai solusi kesepakatan dalam menangani permasalahan yang multikriteria[2].

Metode yang digunakan dalam penyelesaian masalah adalah sistem penunjang keputusan kelompok yang dilakukan dengan perkalian dari nilai referensinya dengan bobot dari ranking. Metode borda adalah peringkatan pada tiap alternatif-alternatif yang ada. Alternatif yang mempunyai peringkat teratasd yang benilai tinggi, yang seharusnya secara menurun diberikan nilai lebih rendah untuk peringkat dibawahnya sampai pada peringkat terendah yang bernilai 0 atau 1 . Borda menentukan pemenang yang mempuanyai point terbanyak. Cara kerja metode Borda yaitu dengan memberikan suatu nilai terbanyak untuk masing-masing kandidat sesuai dengan rangking yang telah di atur oleh masing-masing pengambil keputusan. Pemenang akan ditentukan oleh banyaknya jumlah point yang dikumpul atau diperoleh dari masing-masing kandidat[3].

\subsection{Sistem Pendukung Keputusan}

\section{LANDASAN TEORI}

Sistem pendukung keputusan (Decision Support System) merupakan sistem informasi interaktif yang menyediakan informasi, pemodelan dan pemanipulasian data. Sistem itu digunakan untuk membantu pengambilan keputusan dalam situasi yang semiterstruktur dan situasi yang tidak terstruktur dimana tak seorang pun tahu secara pasti bagaimana keputusan seharusnya dibua[4].

Dengan pengertian diatas dapat disimpulkan bahwa SPK bukan merupakan alat pengambilan keputusan, melainkan merupakan sistem yang membantu pengambil keputusan dengan melengkapi mereka dengan informasi dari data yang telah diolah dengan relevan dan diperlukan untuk membuat keputusan tentang suatu masalah dengan lebih cepat dan akurat. Sehingga sistem ini tidak dimaksudkan untuk menggantikan pengambilan keputusan dalam proses pembuatan keputusan.

\subsection{Metode VIKOR}

VIKOR merupakan metode perangking dengan menggunakan indeks peringkat multikriteria derdasarkan ukuran tertentu dari kedekatan dengan solusi yang ideal[7]. Konsep dasar vikor adalah menentukan rangking dari sampel-sampel yang ada dengan melihat hasil dari nilai-nilai utilitas dan regrert dari setiap sample. Metode VIKOR telah digunakan oleh beberapa peneliti dalam MCDM, seperti dalam pemilihan vendor. Masalah MCDM dapat direpresentasikan oleh matriks, dimana kolom menunjukan kriteria (atribut) dengan mempertimbangkan masalah yang diberikan dan baris menunjukkan alternatif.

VIKOR digunakan untuk mengatasi permasalahan multikriteria sistem yang kompleks yang berfokus pada rangking dan seleksi dari sebuah alternatif. Selain itu metode ini memiliki kelebihan dalam kompromi alternatif. Prosedur yang diusulkan pertama menghitung solusi yang ideal dan negatif ideal setiap kriteria dengan mempertimbangkan kriteria dan bobot setiap alternatif, dan utilitas yang sesuai dan ukuran seselan (regrel) untuk setiap alternatif yang telah ditentukan. Penelitian ini bertujuan untuk menyelesaikan permasalahan pemilihan colon penerima beasiswa bidikmasi dengan metode VIKOR dalam penyeleksian penerimaan beasiswa di Universitas Terbuka?. Hasil analisis Metode VIKOR, diharapkan dapat digunakan sebagai pendukung keputusan bagi mahasiswa dalam menetukan calon penerima beasiswa.

Metode VIKOR di gunakan dalam sistem yang kompleks, Metode ini berfokus pada perangkingan dan memilih dari satu set alternatif, dan menentukan solusi kompromi untuk masalah kriteria yang 
bertentangan, yang dapat membantu para pengambil keputusan untuk mencapai keputusan akhir. Di sini, solusi kompromi adalah solusi yang layak yang paling dekat dengan ideal, dan kompromi berarti perjanjian didirikan dengan konsesi.

Langkah-langkah yang dilakukan dalam penyelesaian masalah menggunakan metode VIKOR sebagai berikut[8] :

$$
X=\begin{array}{cccccc} 
& C_{1} & C_{2} & C_{3} & & C_{5} \\
A_{1} & x_{11} & x_{12} & x_{13} & \vdots & x_{1 n} \\
A_{2} & x_{21} & x_{22} & x_{32} & \vdots & x_{2 c} \\
A_{3} & x_{31} & x_{32} & x_{33} & \vdots & x_{3 c} \\
\vdots & \vdots & \vdots & \vdots & \ddots & \vdots \\
A_{n} & x_{n 1} & x_{n 2} & x_{n 3} & \ldots & x_{n c}
\end{array}
$$

a. Melakukan normalisasi menggunakan rumus sebagai berikut:

$R_{i j}=\left(\frac{x_{j}^{+}-X_{i j}}{X_{j}^{+}-X_{j}^{-}}\right)$

Dimana $R_{i j}$ dan $X_{i j}(i=1,2,3, \ldots, m$ dan $j=1,2,3, \ldots, n)$ adalah elemen dari matriks pengambilan keputusan (alternatif $\mathrm{i}$ terhadap kriteria $\mathrm{j}$ ) dan $\mathrm{X}_{\mathrm{j}}^{+}$adalah elemen terbaik dari kriteria $\mathrm{j}, \mathrm{X}^{-}{ }_{\mathrm{j}}$ adalah elemen terburuk dari kriteria $\mathrm{j}$.

b. Menghitung nilai $\mathrm{S}$ dan $\mathrm{R}$ menggunakan rumus sebagai berikut:

$$
\begin{aligned}
\mathrm{S}_{\mathrm{i}} & =\sum_{j=1}^{n} \mathrm{w}_{\mathrm{j}}\left(\frac{\mathrm{x}_{\mathrm{j}}^{+}-\mathrm{x}_{\mathrm{ij}}}{\mathrm{x}_{\mathrm{j}}^{+}-\mathrm{x}_{\mathrm{j}}^{-}}\right) \quad \mathrm{dan} \\
\mathrm{R}_{\mathrm{i}} & =\operatorname{Max} j\left[\mathrm{w}_{\mathrm{j}}\left(\frac{\mathrm{x}_{\mathrm{j}}^{+}-\mathrm{x}_{\mathrm{ij}}}{\mathrm{x}_{\mathrm{j}}^{+}-\mathrm{x}_{\mathrm{j}}^{-}}\right)\right] \ldots \ldots \ldots \ldots \ldots \ldots \ldots \ldots \ldots \ldots \ldots \ldots \ldots \ldots \ldots \ldots \ldots \ldots \ldots \ldots \ldots \ldots \ldots \ldots \ldots \ldots \ldots \ldots \ldots \ldots \ldots \ldots \ldots \ldots
\end{aligned}
$$

Dimana $\mathrm{W}_{\mathrm{j}}$ adalah bobot dari tiap kriteria $\mathrm{j}$

c. Menentukan nilai indeks

$$
\mathrm{Q}_{\mathrm{i}}=\left[\frac{S_{i}-S^{+}}{S^{+}-S^{-}}\right] \mathrm{v}+\left[\frac{R_{i}-R^{+}}{R^{+}-R^{-}}\right](1-\mathrm{v})
$$

Dimana $S^{-}=\max S_{i}, S^{+}=\min S_{i}$ dan $R^{-}=\max R_{i}, R^{+}=\min R_{i}$ dan $v=0,5$.

d. Hasil perangkingan merupakan hasil pengurutan dari $S, R$ dan $Q$

e. Solusi alternatif peringkat terbaik berdasarkan dengan nilai $\mathrm{Q}$ minimum menjadi peringkat terbaik dengan syarat:

$$
\text { 1. } \mathrm{Q}\left(\mathrm{A}^{(2)}\right)-\mathrm{Q}\left(\mathrm{A}^{(1)}\right) \geq \mathrm{DQ}
$$

Dimana $\mathrm{A}^{(2)}=$ alternatif dengan urutan kedua pada perangkingan $\mathrm{Q}$ dan

$\mathrm{A}^{(1)}=$ alternatif dengan urutan terbaik pada perangkingan $\mathrm{Q}$ sedangkan

$\mathrm{DQ}=1-(\mathrm{m}-1)$, dimana $\mathrm{m}$ merupakan jumlah alernatif.

Alternatif $\mathrm{A}^{(1)}$ harus berada pada rangking terbaik pada $\mathrm{S}$ dan/atau $\mathrm{R}$

\subsection{Metode BORDA}

Prinsip metode borda adalah memberikan peringkat pada alternatif-alternatif yang ada. Alternatif yang mempunyai peringkat teratas diberinilai tertinggi, demikian seterusnya secara menurun diberikan nilai lebih rendah untuk peringkat dibawahnya sampai pada peringkat terendah diberinilai 0 atau 1 . Ide dari metode Borda adalah mengharuskan para pemilih memberikan rangking kepada tiap kandidat, serta memberikan nilai untuk tiap-tiap peringkat misalnya, yaitu peringkat pertama diberikan nilai 2, peringkat kedua diberikan nilai 1 , dan peringkat ketiga diberikan nilai 0 .

Pengertian lain borda merupakan suatu metode votting yang digunakan pada pengambilan keputusan kelompok untuk pemilihan single winner ataupun multiple winner. Borda menentukan pemenang dengan memberikan sejumlah nilai tertentu untuk masing-masing alternatif. Selanjutnya pemenang akan ditentukan oleh banyaknya jumlah nilai yang dikumpulkan alternatif. Pada sistem pendukung keputusan kelompok salah satu masalah yang sering dihadapi adalah bagaimana mengagregasikan opini-opini dari para pengambil keputusan untuk menghasilkan suatu keputusan yang tepat[9]. 


\subsection{Analisa Masalah}

\section{HASIL DAN PEMBAHASAN}

Sistem pendukung keputusan penyeleksian colour guard merupakan suatu sistem yang dibuat untuk memenuhi anggota pada marching band GINADA yang diinginkan oleh pelatih serta mendapatkan anggota yang benar-benar meiliki potensi yang cukup berbakat dalam bidang colour guard. Dalam sistem penyeleksian colour guard ini dapat membantu pelatih, guru dan senior sesuai dengan kriteria yang sudah ditentukan. Analisa masalah dilakukan untuk mendapatkan gambaran secara lengkap mengenai permasalahan yang ada.

Didalam menyeleksi anggota calon colour guard pada marching band GINADA, penulis hanya mengambil 15 sample nama di sekolah SMA Teladan Sei Rampah. Pada perhitungan awal, 15 nama yang akan diseleksi menggunakan metode VIKOR. Hasil dari metode VIKOR, kemudian diseleksi kembali dan di ambil 10 nama untuk diseleksi kembali menggunakan metode Borda. Hasil dari metode Borda kemudian dibagi untuk masing-masing event yang akan diadakan dilokasi perlombaan.

Kegiatan penyeleksian colour guard merupakan suatu kegiatan yang dilakukan oleh pelatih. Namun penyeleksian yang tepat sesuai dengan potensi yang terbaik dan bukan hal mudah. Banyaknya yang diseleksi bisa jadi membuat bingung dalam penyeleksian. Jenis-jenis kriteria yang sudah ditentukan untuk sebagai tujuan akhir penentu. Kriteria yang sudah ditentukan yaitu; tinggi, berat badan, kelincahan, stamina dan bahasa tubuh.

Dalam penyeleksian colour guard pada marching band GINADA beberapa hal yang menjadi permasalahan antara lain yaitu penyeleksian secara objektif dan subjektif. Subjektif yaitu penyeleksian yang didasari dimana seseorang akan berpikir secara relatif dengan hasil yang menduga, dan menggunakan perasaan, walaupun berdasarkan kriteria yang ada, sedangkan objektif yaitu penyeleksian yang didasari sikap yang harus menjunjung tinggi seseorang yang berdasarkan pandangan terhadap suatu masalah. Oleh karena itu, dibutuhkan suatu sistem pendukung keputusan dimana penyeleksian yang dilakukan secara subjektif dan objektif. Maka dari itu, dalam penyeleksian colour guard pada marching band GINADA digunakan metode VIKOR dan Borda.

Metode VIKOR merupakan penentuan ranking dari sampel-sampel yang sudah ada dengan melihat hasil dari nilai utilitas, regres dan jarak solusi sebagai alternatif terbaik dari setiap sampel dengan pembobotan kriteria dari metode Analysis Hierarchy Proses. Metode yang digunakan dalam penyelesaian masalah adalah sistem penunjang keputusan kelompok yang dilakukan dengan perkalian dari nilai referensinya dengan bobot dari ranking.

Metode borda adalah peringkatan pada tiap alternatif-alternatif yang ada. Alternatif yang mempunyai peringkat teratasd yang benilai tinggi, yang seharusnya secara menurun diberikan nilai lebih rendah untuk peringkat dibawahnya sampai pada peringkat terendah yang bernilai 0 atau 1 . Borda menentukan pemenang yang mempuanyai point terbanyak

\subsection{Penerapan Metode Vikor}

Dalam penyeleksian colour guard pada marching band GINADA, sesuai dengan metode Vise Kriterijumska Optimizacija Kompromisno Resenje (VIKOR) dan Borda yang merupakan penyelesaian masalah dengan diperlukan adanya kriteria-kriteria dan bobot untuk melakukan proses perhitungannya sehingga akan didapat alternatif terbaik, dalam penelitian ini alternatif yang dimaksud penulis adalah penyeleksian colour guard yang akan bergabung pada marching band GINADA.

Tabel 1. Rating Kecocokan Dari Setiap Alternatif Pada Setiap Kriteria

\begin{tabular}{|c|c|c|c|c|c|}
\hline \multirow{2}{*}{ Alternatif } & \multicolumn{5}{|c|}{ Kriteria } \\
\cline { 2 - 6 } & $\mathbf{C 1}$ & $\mathbf{C 2}$ & $\mathbf{C 3}$ & $\mathbf{C 4}$ & $\mathbf{C} 5$ \\
\hline A1 & 158 & 55 & 60 & 100 & 80 \\
\hline A2 & 155 & 63 & 65 & 80 & 60 \\
\hline A3 & 167 & 64 & 60 & 90 & 60 \\
\hline A4 & 165 & 53 & 70 & 70 & 65 \\
\hline A5 & 172 & 63 & 100 & 90 & 75 \\
\hline A6 & 170 & 47 & 100 & 95 & 70 \\
\hline
\end{tabular}




\begin{tabular}{|c|c|c|c|c|c|}
\hline \multirow{2}{*}{ Alternatif } & \multicolumn{5}{|c|}{ Kriteria } \\
\cline { 2 - 6 } & \multirow{2}{*}{ C1 } & $\mathbf{C 2}$ & $\mathbf{C 3}$ & $\mathbf{C 4}$ & $\mathbf{C 5}$ \\
\hline A7 & 162 & 58 & 50 & 50 & 80 \\
\hline A8 & 168 & 58 & 60 & 90 & 60 \\
\hline A9 & 158 & 52 & 70 & 100 & 60 \\
\hline A10 & 165 & 59 & 75 & 70 & 65 \\
\hline A11 & 170 & 60 & 90 & 90 & 75 \\
\hline A12 & 175 & 51 & 70 & 50 & 85 \\
\hline A13 & 155 & 65 & 80 & 70 & 85 \\
\hline A14 & 171 & 61 & 80 & 75 & 80 \\
\hline A15 & 171 & 50 & 79 & 50 & 60 \\
\hline MAX & 175 & 65 & 100 & 100 & 85 \\
\hline MIN & 155 & 46 & 50 & 50 & 60 \\
\hline
\end{tabular}

Metode Vikor (Vlse Kriterijumska Optimizacija I Kompromisno Resenje) merupakan salah satu metode yang didasarkan pada perangkingan dan pemilihan dari sekumpulan alternatif yang ada, dapat digunakan untuk merangking banyak kriteria baik itu kualitatif maupun kuantitatif. Dalam proses evaluasi dan pemilihan, akan didasarkan pada kriteria-kriteria yang telah ditetapkan oleh perusahaan terhadap alternatif-alternatif yang ada. Maka dari itu, metode Vikor sangat sesuai untuk mengambil keputusan dalam penentuan penerimaan jurnalis baru.

Langkah-langkah menghitung nilai kriteria dengan metode Vikor:

a. Melakukan normalisasi data

Normalisasi dengan menggunakan rumus pada perasaan Vikor dengan hasil perhitungan sebagai berikut:

Rumus: $R_{i j}=\left(\frac{x_{j}^{+}-X_{i j}}{x_{j}^{+}-X_{j}^{-}}\right)$

Keterangan:

$\mathrm{i}=$ Alternatif / Baris

$\mathrm{j} \quad=$ Kriteria / Kolom

Xij = Nilai dari matriks pengambilan keputusan

$\mathrm{X}_{\mathrm{j}}{ }^{+}=$Nilai terbaik dalam satu kriteria

$\mathrm{X}_{\mathrm{j}^{-}}=$Nilai terjelek dalam satu kriteria

Dari tabel nilai masing-masing kriteria akan dilakukan normalisasi data, yaitu:

1. Kriteria untuk $\mathrm{C} 1$

$$
\begin{aligned}
& \mathrm{R}(\mathrm{A} 1), \mathrm{C} 1=\frac{(175-158)}{(175-155)}=\frac{17}{20}=0.85 \\
& \mathrm{R}(\mathrm{A} 2), \mathrm{C} 1=\frac{(175-155)}{(175-155)}=\frac{20}{20}=1 \\
& \mathrm{R}(\mathrm{A} 3), \mathrm{C} 1=\frac{(175-167)}{(175-155)}=\frac{8}{20}=0,4 \\
& \mathrm{R}(\mathrm{A} 4), \mathrm{C} 1=\frac{(175-165)}{(175-155)}=\frac{10}{20}=0,5 \\
& \mathrm{R}(\mathrm{A} 5), \mathrm{C} 1=\frac{(175-172)}{(175-155)}=\frac{2}{20}=0,15 \\
& \mathrm{R}(\mathrm{A} 6), \mathrm{C} 1=\frac{(175-170)}{(175-155)}=\frac{5}{20}=0,25 \\
& \mathrm{R}(\mathrm{A} 7), \mathrm{C} 1=\frac{(175-162)}{(175-155)}=\frac{13}{20}=0,065 \\
& \mathrm{R}(\mathrm{A} 8), \mathrm{C} 1=\frac{(175-168)}{(175-155)}=\frac{7}{20}=0,35 \\
& \mathrm{R}(\mathrm{A} 9), \mathrm{C} 1=\frac{(175-168)}{(175-155)}=\frac{7}{20}=0,35 \\
& \mathrm{R}(\mathrm{A} 10), \mathrm{C} 1=\frac{(175-165)}{(175-155)}=\frac{10}{20}=0,5 \\
& \mathrm{R}(\mathrm{A} 11), \mathrm{C} 1=\frac{(175-170)}{(175-155)}=\frac{5}{20}=0,25
\end{aligned}
$$


$\mathrm{R}(\mathrm{A} 12), \mathrm{C} 1=\frac{(175-175)}{(175-155)}=\frac{0}{20}=0$
$\mathrm{R}(\mathrm{A} 13), \mathrm{C} 1=\frac{(175-155)}{(175-155)}=\frac{20}{20}=1$
$\mathrm{R}(\mathrm{A} 14), \mathrm{C} 1=\frac{(175-171)}{(175-155)}=\frac{4}{20}=0,2$
$\mathrm{R}(\mathrm{A} 15), \mathrm{C} 1=\frac{(175-171)}{(175-155)}=\frac{4}{20}=0,2$

2. Kriteria untuk $\mathrm{C} 2$

$\mathrm{R}(\mathrm{A} 1), \mathrm{C} 2=\frac{(65-55)}{(64-46)}=\frac{10}{19}=0,5263$
$\mathrm{R}(\mathrm{A} 2), \mathrm{C} 2=\frac{(65-63)}{(64-46)}=\frac{2}{19}=0,1052$
$\mathrm{R}(\mathrm{A} 3), \mathrm{C} 2=\frac{(65-64)}{(64-46)}=\frac{1}{19}=0,0526$
$\mathrm{R}(\mathrm{A} 4), \mathrm{C} 2=\frac{(65-53)}{(65-46)}=\frac{12}{19}=0,6316$
$\mathrm{R}(\mathrm{A} 5), \mathrm{C} 2=\frac{(65-63)}{(64-46)}=\frac{2}{19}=0,1053$
$\mathrm{R}(\mathrm{A} 6), \mathrm{C} 2=\frac{(65-47)}{(64-46)}=\frac{18}{19}=0,9474$
$\mathrm{R}(\mathrm{A} 7), \mathrm{C} 2=\frac{(65-58)}{(64-46)}=\frac{7}{19}=0,3684$
$\mathrm{R}(\mathrm{A} 8), \mathrm{C} 2=\frac{(65-58)}{(64-46)}=\frac{7}{19}=0,3684$
$\mathrm{R}(\mathrm{A} 9), \mathrm{C} 2=\frac{(65-52)}{(65-46)}=\frac{13}{19}=0,6842$
$\mathrm{R}(\mathrm{A} 10), \mathrm{C} 2=\frac{(65-59)}{(64-46)}=\frac{46}{19}=0,3158$
$\mathrm{R}(\mathrm{A} 11), \mathrm{C} 2=\frac{(65-60)}{(64-46)}=\frac{5}{19}=0,2631$
$\mathrm{R}(\mathrm{A} 12), \mathrm{C} 2=\frac{(65-51)}{(64-46)}=\frac{14}{19}=0,7368$
$\mathrm{R}(\mathrm{A} 13), \mathrm{C} 2=\frac{(65-65)}{(64-46)}=\frac{0}{19}=0$
$\mathrm{R}(\mathrm{A} 14), \mathrm{C} 2=\frac{(65-61)}{(65-46)}=\frac{4}{19}=0,2105$
$\mathrm{R}(\mathrm{A} 15), \mathrm{C} 2=\frac{(65-50)}{(64-46)}=\frac{15}{19}=0,7895$
$\mathrm{~K}$

3. Kriteria untuk $\mathrm{C} 3$
$\mathrm{R}(\mathrm{A} 1), \mathrm{C} 4=\frac{(100-60)}{(100-50)}=\frac{40}{50}=0,8$
$\mathrm{R}(\mathrm{A} 2), \mathrm{C} 4=\frac{(100-65)}{(100-50)}=\frac{35}{50}=0,7$
$\mathrm{R}(\mathrm{A} 3), \mathrm{C} 4=\frac{(100-60)}{(100-50)}=\frac{40}{50}=0,8$
$\mathrm{R}(\mathrm{A} 4), \mathrm{C} 4=\frac{(100-70)}{(100-50)}=\frac{30}{50}=0,6$
$\mathrm{R}(\mathrm{A} 5), \mathrm{C} 4=\frac{(100-100)}{(100-50)}=\frac{0}{50}=0$
$\mathrm{R}(\mathrm{A} 6), \mathrm{C} 4=\frac{(100-100)}{(100-50)}=\frac{0}{50}=0$
$\mathrm{R}(\mathrm{A} 7), \mathrm{C} 4=\frac{(100-50)}{(100-50)}=\frac{50}{50}=1$
$\mathrm{R}(\mathrm{A} 8), \mathrm{C} 4=\frac{(100-60)}{(100-50)}=\frac{40}{50}=0,8$
$\mathrm{R}$ (A9), C4 $=\frac{(100-70)}{(100-50)}=\frac{30}{50}=0,6$
$\mathrm{R}$ (A10), $\mathrm{C} 4=\frac{(100-75)}{(100-50)}=\frac{25}{50}=0,5$
$\mathrm{R}(\mathrm{A} 11), \mathrm{C} 4=\frac{(100-90)}{(100-50)}=\frac{10}{50}=0,2$ 
$\mathrm{R}(\mathrm{A} 12), \mathrm{C} 4=\frac{(100-70)}{(100-50)}=\frac{30}{50}=0,6$
$\mathrm{R}(\mathrm{A} 13), \mathrm{C} 4=\frac{(100-70)}{(100-50)}=\frac{30}{50}=0,6$
$\mathrm{R}(\mathrm{A} 14), \mathrm{C} 4=\frac{(100-75)}{(100-50)}=\frac{25}{50}=0,5$
$\mathrm{R}(\mathrm{A} 15), \mathrm{C} 4=\frac{(100-50)}{(100-50)}=\frac{50}{50}=1$

4. Kriteria untuk $\mathrm{C} 4$
$\mathrm{R}(\mathrm{A} 1), \mathrm{C} 4=\frac{(100-100)}{(100-50)}=\frac{0}{50}=0$
$\mathrm{R}(\mathrm{A} 2), \mathrm{C} 4=\frac{(100-80)}{(100-50)}=\frac{20}{50}=0,004$
$\mathrm{R}(\mathrm{A} 3), \mathrm{C} 4=\frac{(100-90)}{(100-50)}=\frac{10}{50}=0,2$
$\mathrm{R}$ (A4), C4 $=\frac{(100-70)}{(100-50)}=\frac{30}{50}=0,6$
$\mathrm{R}(\mathrm{A} 5), \mathrm{C} 4=\frac{(100-90)}{(100-50)}=\frac{10}{50}=0,2$
$\mathrm{R}$ (A6), C4 $=\frac{(100-95)}{(100-50)}=\frac{5}{50}=0,1$
$\mathrm{R}(\mathrm{A} 7), \mathrm{C} 4=\frac{(100-50)}{(100-50)}=\frac{50}{50}=1$
$\mathrm{R}(\mathrm{A} 8), \mathrm{C} 4=\frac{(100-90)}{(100-50)}=\frac{10}{50}=0,2$
$\mathrm{R}$ (A9), $\mathrm{C} 4=\frac{(100-100)}{(100-50)}=\frac{0}{50}=0$
$\mathrm{R}$ (A10), C4 $=\frac{(100-70)}{(100-50)}=\frac{30}{50}=0,6$
$\mathrm{R}$ (A11), C4 $=\frac{(100-90)}{(100-50)}=\frac{10}{50}=0,2$
$\mathrm{R}(\mathrm{A} 12), \mathrm{C} 4=\frac{(100-50)}{(100-50)}=\frac{50}{50}=1$
$\mathrm{R}$ (A13), C4 $=\frac{(100-70)}{(100-50)}=\frac{30}{50}=0,6$
$\mathrm{R}(\mathrm{A} 14), \mathrm{C} 4=\frac{(100-70)}{(100-50)}=\frac{30}{50}=0,6$
$\mathrm{R}(\mathrm{A} 15), \mathrm{C} 4=\frac{(100-50)}{(100-50)}=\frac{50}{50}=1$

5. Kriteria untuk $C 5$
$\mathrm{R}(\mathrm{A} 1), \mathrm{C} 5=\frac{(85-80)}{(85-60)}=\frac{5}{25}=0,2$
$\mathrm{R}(\mathrm{A} 2), \mathrm{C} 5=\frac{(85-60)}{(85-60)}=\frac{5}{25}=1$
$\mathrm{R}(\mathrm{A} 3), \mathrm{C} 5=\frac{(85-60)}{(85-60)}=\frac{5}{25}=1$
$\mathrm{R}(\mathrm{A} 4), \mathrm{C} 5=\frac{(85-65)}{(85-60)}=\frac{5}{25}=0,8$
$\mathrm{R}(\mathrm{A} 5), \mathrm{C} 5=\frac{(85-75)}{(85-60)}=\frac{5}{25}=0,4$
$\mathrm{R}(\mathrm{A} 6), \mathrm{C} 5=\frac{(85-70)}{(85-60)}=\frac{15}{25}=0,4$
$\mathrm{R}(\mathrm{A} 7), \mathrm{C} 5=\frac{(85-80)}{(85-60)}=\frac{5}{25}=0,2$
$\mathrm{R}$ (A8), C5 $=\frac{(85-80)}{(85-60)}=\frac{5}{25}=1$
$\mathrm{R}$ (A9), C $5=\frac{(85-60)}{(85-60)}=\frac{25}{25}=1$
$\mathrm{R}$ (A10), C $5=\frac{(85-65)}{(85-60)}=\frac{20}{25}=0,8$
$\mathrm{R}(\mathrm{A} 11), \mathrm{C} 5=\frac{(85-75)}{(85-60)}=\frac{10}{25}=0,4$ 
$\mathrm{R}(\mathrm{A} 12), \mathrm{C} 5=\frac{(85-85)}{(85-60)}=\frac{0}{25}=0$

$\mathrm{R}(\mathrm{A} 13), \mathrm{C} 5=\frac{(85-85)}{(85-60)}=\frac{0}{25}=0$

$\mathrm{R}(\mathrm{A} 14), \mathrm{C} 5=\frac{(85-80)}{(85-60)}=\frac{5}{25}=0,2$

$\mathrm{R}(\mathrm{A} 15), \mathrm{C} 5=\frac{(85-60)}{(85-60)}=\frac{25}{25}=1$

Dengan langkah-langkah perhitungan diatas maka didapatkan data normalisasi semua sampel, berikut disajikan tabel data normalisasi semua sampel (normalisasi matriks).

Tabel 2. Normalisasi Matriks

\begin{tabular}{|c|c|c|c|c|c|}
\hline \multirow{2}{*}{ Alternatif } & \multicolumn{5}{|c|}{ Kriteria } \\
\cline { 2 - 6 } & C1 & C2 & C3 & C4 & C5 \\
\hline A1 & 0.85 & 0,5263 & 0,7864 & 0,3846 & 0,2 \\
\hline $\mathbf{A 2}$ & 1 & 0,1052 & 0,7076 & 0,876923 & 1 \\
\hline $\mathbf{A 3}$ & 0,4 & 0,0526 & 0,6153 & 0,2307 & 1 \\
\hline $\mathbf{A 4}$ & 0,5 & 0,6315 & 0,2923 & 0,4923 & 0,8 \\
\hline $\mathbf{A 5}$ & 0,15 & 0,1052 & 0,1384 & 0,3077 & 0,4 \\
\hline $\mathbf{A 6}$ & 0,25 & 0,9473 & 0 & 0,29237077 & 0,6 \\
\hline $\mathbf{A 7}$ & 0,65 & 0,3684 & 0,8307 & 0,7077 & 0,2 \\
\hline $\mathbf{A 8}$ & 0,35 & 0,6842 & 0,8 & 0 & 1 \\
\hline $\mathbf{A 9}$ & 0,35 & 0,6842 & 0,4615 & 0,1692 & 1 \\
\hline $\mathbf{A 1 0}$ & 0,5 & 0,3158 & 0,3076 & 0,8308 & 0,8 \\
\hline $\mathbf{A 1 1}$ & 0,25 & 0,2631 & 0,1384 & 0,2615 & 0,4 \\
\hline $\mathbf{A 1 2}$ & 0 & 0,7368 & 0,0615 & 0,8462 & 0 \\
\hline $\mathbf{A 1 3}$ & 1 & 0 & 0,2769 & 0,44 & 0 \\
\hline $\mathbf{A 1 4}$ & 0,2 & 0,2105 & 0,0769 & 0,369292 & 0,2 \\
\hline $\mathbf{A 1 5}$ & 0.85 & 0,7895 & 0,0923 & 0,9231 & 1 \\
\hline
\end{tabular}

Tabel 3. Normalisasi x Bobot

\begin{tabular}{|c|c|c|c|c|c|}
\hline \multirow{2}{*}{ Alternatif } & \multicolumn{5}{|c|}{ Kriteria } \\
\cline { 2 - 6 } & $\mathbf{C 1}$ & $\mathbf{C 2}$ & $\mathbf{C 3}$ & $\mathbf{C 4}$ & $\mathbf{C 5}$ \\
\hline $\mathbf{A 1}$ & $0.85^{*} 0,30$ & $0,5263^{*} 0,25$ & $0,8^{*} 0,20$ & $0^{*} 0,15$ & $0,2^{*} 0,10$ \\
\hline $\mathbf{A 2}$ & $1^{*} 0,30$ & $0,1052^{*} 0,25$ & $0,7^{*} 0,20$ & $0,004^{*} 0,1523$ & $1 * 0,10$ \\
\hline $\mathbf{A 3}$ & $0,4^{*} 0,30$ & $0,0526^{*} 0,25$ & $0,8^{*} 0,20$ & $0,2^{*} 0,15$ & $1^{*} 0,10$ \\
\hline $\mathbf{A 4}$ & $0,5^{*} 0,30$ & $0,6315^{*} 0,25$ & $0,6^{*} 0,20$ & $0,6^{*} 0,15$ & $0,8^{*} 0,10$ \\
\hline $\mathbf{A 5}$ & $0,15^{*} 0,30$ & $0,1052^{*} 0,25$ & $0^{*} 0,20$ & $0,2^{*} 0,15$ & $0,4^{*} 0,10$ \\
\hline $\mathbf{A 6}$ & $0,25^{*} 0,30$ & $0,9473^{*} 0,25$ & $0^{*} 0,20$ & $0,1^{*} 0,157077$ & $0,6^{*} 0,10$ \\
\hline $\mathbf{A 7}$ & $0,65^{*} 0,30$ & $0,3684^{*} 0,25$ & $1^{*} 0,20$ & $1^{*} 0,15$ & $0,2 * 0,10$ \\
\hline $\mathbf{A 8}$ & $0,35^{*} 0,30$ & $0,6842^{*} 0,25$ & $0,8^{*} 0,20$ & $0,2^{*} 0,15$ & $1 * 0,10$ \\
\hline $\mathbf{A 9}$ & $0,35^{*} 0,30$ & $0,6842^{*} 0,25$ & $0,6^{*} 0,20$ & $0^{*} 0,15$ & $1 * 0,10$ \\
\hline $\mathbf{A 1 0}$ & $0,5^{*} 0,30$ & $0,3158^{*} 0,25$ & $0,5^{*} 0,20$ & $0,6^{*} 0,15$ & $0,8^{*} 0,10$ \\
\hline $\mathbf{A 1 1}$ & $0,25^{*} 0,30$ & $0,2631^{*} 0,25$ & $0,2^{*} 0,20$ & $0,2^{*} 0,15$ & $0,4 * 0,10$ \\
\hline $\mathbf{A 1 2}$ & $0^{*} 0,30$ & $0,7368^{*} 0,25$ & $0,6^{*} 0,20$ & $1^{*} 0,15$ & $0 * 0,10$ \\
\hline $\mathbf{A 1 3}$ & $1^{*} 0,30$ & $00^{*} 0,25$ & $0,6^{*} 0,20$ & $0,6^{*} 0,15$ & $0 * 0,10$ \\
\hline $\mathbf{A 1 4}$ & $0,2^{*} 0,30$ & $0,2105^{*} 0,25$ & $0,5^{*} 0,20$ & $0,6^{*} 0,15$ & $0,2^{*} 0,10$ \\
\hline $\mathbf{A 1 5}$ & $0.2^{*} 0,30$ & $0,7895^{*} 0,25$ & $1^{*} 0,20$ & $0,1^{*} 0,15$ & $1 * 0,10$ \\
\hline
\end{tabular}

Tabel 4. Hasil Normalisasi x Bobot 


\begin{tabular}{|c|c|c|c|c|c|}
\hline & C1 & C2 & C3 & C4 & C5 \\
\hline $\mathbf{A 1}$ & 0,255 & 0,1316 & 0,16 & 0 & 0,02 \\
\hline $\mathbf{A 2}$ & 0,30 & 0,0263 & 0,14 & 0,02 & 0,1 \\
\hline $\mathbf{A 3}$ & 0,12 & 0,0132 & 0,16 & 0,03 & 0,1 \\
\hline $\mathbf{A 4}$ & 0,15 & 0,1579 & 0,12 & 0,09 & 0,08 \\
\hline $\mathbf{A 5}$ & 0,045 & 0,0263 & 0 & 0,03 & 0,04 \\
\hline $\mathbf{A 6}$ & 0,075 & 0,2369 & 0 & 0,015 & 0,06 \\
\hline $\mathbf{A 7}$ & 0,195 & 0,0921 & 0,2 & 0,15 & 0,02 \\
\hline $\mathbf{A 8}$ & 0,105 & 0,0921 & 0,16 & 0,03 & 0,1 \\
\hline $\mathbf{A 9}$ & 0,105 & 0,1711 & 0,12 & 0 & 0,1 \\
\hline $\mathbf{A 1 0}$ & 0,15 & 0,079 & 0,1 & 0,09 & 0,08 \\
\hline $\mathbf{A 1 1}$ & 0,075 & 0,0658 & 0,4 & 0,03 & 0,04 \\
\hline $\mathbf{A 1 2}$ & 0 & 0,1842 & 0,12 & 0,15 & 0 \\
\hline $\mathbf{A 1 3}$ & 0,30 & 0 & 0,12 & 0,09 & 0 \\
\hline $\mathbf{A 1 4}$ & 0,06 & 0,0526 & 0,1 & 0,09 & 0,2 \\
\hline $\mathbf{A 1 5}$ & 0,06 & 0,1974 & 0,2 & 0,15 & 0,1 \\
\hline
\end{tabular}

b. Menghitung Nilai $\mathrm{S}$ dan $\mathrm{R}$

Rumus $\mathrm{S}_{\mathrm{i}}=\sum_{j=1}^{n} w j x(R i j)$

$\mathrm{wj}=$ bobot kriteria

Nilai S didapatkan dari penjumlahan hasil perkalian bobot kriteria dengan data pada setiap sampel.

Berikut ini disajikan perhitungan nilai $\mathrm{S}$.

$$
\begin{aligned}
& \mathrm{S}(\mathrm{A} 1)=0,255+0,1316+0,16+0+0,02 \\
& =0,5682 \\
& \mathrm{~S}(\mathrm{~A} 2) \quad=0,30+0,0263+0,14+0,002+0,1 \\
& =0,5683 \\
& \mathrm{~S}(\mathrm{~A} 3) \quad=0,12+0,0132+0,16+0,03+0,1 \\
& =0,4232 \\
& \mathrm{~S}(\mathrm{~A} 4) \quad=0,15+0,1579+0,12+0,09+0,08 \\
& =0,5979 \\
& \mathrm{~S}(\mathrm{~A} 5) \quad=0,045+0,0263+0+0,03+0,04 \\
& =0,1413 \\
& \mathrm{~S} \text { (A6) } \quad=0,075+0,2369+0+0,015+0,06 \\
& =0,3869 \\
& \mathrm{~S}(\mathrm{~A} 7) \quad=0,195+0,0921+0,2+0,15+0,02 \\
& =0,6571 \\
& \mathrm{~S}(\mathrm{~A} 8) \quad=0,105+0,0921+0,16+0,03+0,1 \\
& =0,4871 \\
& \mathrm{~S}(\mathrm{~A} 9) \quad=0,105+0,1711+0,12+0+0,1 \\
& =0,496 \\
& \mathrm{~S}(\mathrm{~A} 10)=0,15+0,079+0,1+0,09+0,08 \\
& =0,4989 \\
& \mathrm{~S}(\mathrm{~A} 11)=0,075+0,0658+0,4+0,03+0,04 \\
& =0,6108 \\
& \mathrm{~S}(\mathrm{~A} 12)=0+0,1842+0,12+0,15+0 \\
& =0,4542 \\
& \mathrm{~S}(\mathrm{~A} 13) \quad=0,30+0+0,12+0,09+0 \\
& =0,51 \\
& \mathrm{~S}(\mathrm{~A} 14) \quad=0,06+0,0526+0,1+0,09+0,02 \\
& =0,8626 \\
& \mathrm{~S}(\mathrm{~A} 15) \quad=0,06+0,1974+0,2+0,15+0,1 \\
& =0,7074
\end{aligned}
$$


Rumus $\mathrm{Ri}=\operatorname{Max} \mathrm{j}[w \mathrm{w} \mathrm{x} \mathrm{Rij}]$

Nilai R adalah nilai terbesar dari perkalian bobot kriteria dengan data normalisasi dari setiap sampel.

Berikut nilai $\mathbf{R}$ untuk semua sampel adalah:
$\mathrm{R}(\mathrm{A} 1) \quad=0,255$
$\mathrm{R}(\mathrm{A} 2) \quad=0,30$
$\mathrm{R}(\mathrm{A} 3) \quad=0,16$
$\mathrm{R}(\mathrm{A} 4)=0,1579$
$\mathrm{R}(\mathrm{A} 5) \quad=0,045$
$\mathrm{R}(\mathrm{A} 6)=0,2369$
$\mathrm{R}(\mathrm{A} 7) \quad=0,2$
$\mathrm{R}(\mathrm{A} 8) \quad=0,16$
$\mathrm{R}$ (A9) $=0,1710$
$\mathrm{R}(\mathrm{A} 10)=0,15$
$\mathrm{R}(\mathrm{A} 11)=0,4$
$\mathrm{R}(\mathrm{A} 12)=0,1842$
$\mathrm{R}(\mathrm{A} 13)=0,3$
$\mathrm{R}(\mathrm{A} 14)=0,06$
$\mathrm{R}(\mathrm{A} 15) \quad=0,1974$

Tabel 5. Nilai $S$ dan $R$

\begin{tabular}{|c|c|c|}
\hline Alternatif & S & R \\
\hline A1 & 0,5682 & 0,255 \\
\hline A2 & 0,5683 & 0,30 \\
\hline A3 & 0,4232 & 0,16 \\
\hline A4 & 0,5979 & 0,1579 \\
\hline A5 & 0,1413 & 0,045 \\
\hline A6 & 0,3869 & 0,2369 \\
\hline A7 & 0,6571 & 0,2 \\
\hline A8 & 0,4871 & 0,16 \\
\hline A9 & 0,496 & 0,1710 \\
\hline A10 & 0,4989 & 0,15 \\
\hline A11 & 0,6108 & 0,4 \\
\hline A12 & 0,4542 & 0,1842 \\
\hline A13 & 0,51 & 0,3 \\
\hline A14 & 0,8626 & 0,1 \\
\hline A15 & 0,7074 & 0,2 \\
\hline Max & $\mathbf{8 6 2 6}$ & $\mathbf{0 , 4}$ \\
\hline Min &, $\mathbf{1 4 1 3}$ & $\mathbf{D , 0 4 5}$ \\
\hline
\end{tabular}

c. Menghitung Indeks Vikor

Rumus $\mathrm{Q}_{\mathrm{i}}=\left[\frac{S_{i}-S^{+}}{S^{-}-S^{+}}\right] \mathrm{v}+\left[\frac{R_{i}-R^{+}}{R^{-}-R^{+}}\right](1-\mathrm{v})$

Ket:

$\mathrm{S}^{-}=$nilai $\mathrm{S}$ terbesar

$\mathrm{S}^{+}=$nilai $\mathrm{S}$ terkecil

$$
\mathrm{R}^{-}=\text {nilai } \mathrm{R} \text { terbesar } \quad \mathrm{V}=0,5
$$

$\mathrm{R}^{+}=$nili $\mathrm{R}$ terkecil

Alternatif dengan nilai $\mathrm{Q}$ terkecil merupakan alternatif terbaik. Berikut disajikan perhitungan nilai indeks Vikor $(\mathrm{Q})$ :

$$
\begin{aligned}
\mathrm{Q}(\mathbf{A 1}) & =\left[\frac{0,5682-0,1413}{0,8626-0,1413}\right] * 0,5+\left[\frac{0,255-0,0462}{0,30-0,0462}\right] *(1-0,5) \\
& =\left[\frac{0,4269}{0,7213}\right] * 0,5+\left[\frac{0,21}{0,335}\right] *(0,5) \\
& =(0,5918 * 0,5)+(0,6269 * 0,5) \\
& =0,2967+0,3135=0,708
\end{aligned}
$$




$$
\begin{aligned}
& \mathrm{Q}(\mathbf{A 2})=\left[\frac{0,5683-0,1413}{0,8626-0,1413}\right] * 0,5+\left[\frac{0,30-0,0462}{0,30-0,0462}\right] *(1-0,5) \\
& =\left[\frac{0,427}{0,7213}\right] * 0,5+\left[\frac{0,255}{0,335}\right] *(0,5) \\
& =(0,5919 * 0,5)+(0,7216 * 0,5) \\
& =0,2959+0,3806=0 \text {, } \\
& \left.\mathrm{Q}(\mathbf{A 3})=\left[\frac{0,4232-0,1413}{0,8626-0,1413}\right] * 0,5+\frac{0,16-0,0462}{0,30-0,0462}\right] *(1-0,5) \\
& =\left[\frac{0,2819}{0,7213}\right] * 0,5+\left[\frac{0,115}{0,335}\right] *(0,5) \\
& =(0,3908 * 0,5)+(03433, * 0,5) \\
& =0,1954+0,1717=0,3671 \\
& \left.\mathrm{Q}(\mathbf{A 4})=\left[\frac{0,5975-0,1413}{0,8626-0,1413}\right] * 0,5+\frac{0,1579-0,0462}{0,30-0,0462}\right] *(1-0,5) \\
& =\left[\frac{0,4562}{0,7213}\right] * 0,5+\left[\frac{0,1579}{0,335}\right] *(0,5) \\
& =(0,6325 * 0,5)+(0,1129 * 0,5) \\
& =0,3163+0,3370=0,4848 \\
& \mathrm{Q}(\mathrm{A5})=\left[\frac{0,1413-0,1413}{0,92-0,1852}\right] * 0,5+\left[\frac{0,045-0,0462}{0,30-0,0462}\right] *(1-0,5) \\
& =\left[\frac{0}{0,7213}\right] * 0,5+\left[\frac{0}{0,335}\right] *(0,5) \\
& =(0 * 0,5)+(0 * 0,5) \\
& =0+0=0 \\
& \mathrm{Q}(\mathbf{A 6})=\left[\frac{0,3869-0,1413}{0,8626-0,1413}\right] * 0,5+\left[\frac{0,2369-0,0462}{0,30-0,0462}\right] *(1-0,5) \\
& =\left[\frac{0,2456}{0,7213}\right] * 0,5+\left[\frac{0,1919}{0,335}\right] *(0,5) \\
& =(0,3405 * 0,5)+(0,5728 * 0,5) \\
& =0,1703+0,2864=0,4567 \\
& \left.\mathrm{Q}(\mathrm{A} 7)=\frac{0,6571-0,1413}{0,8626-0,1413}\right] * 0,5+\left[\frac{0,2-0,0462}{0,30-0,0462}\right] *(1-0,5) \\
& =\left[\frac{0,5158}{0,7213}\right] * 0,5+\left[\frac{0,155}{0,335}\right] *(0,5) \\
& =(0,7151 * 0,5)+(0,4627 * 0,5) \\
& =0,3576+0,2314=0,589 \\
& \mathrm{Q}(\mathbf{A 8})=\left[\frac{0,4871-0,1413}{0,8626-0,1413}\right] * 0,5+\left[\frac{0,16-0,0462}{0,30-0,0462}\right] *(1-0,5) \\
& =\left[\frac{0,3458}{0,7213}\right] * 0,5+\left[\frac{0,115}{0,335}\right] *(0,5) \\
& =(0,4794 * 0,5)+(0,3433 * 0,5) \\
& =0,2397+0,1717=04114 \\
& \mathrm{Q} \text { (A9) }=\left[\frac{0,496-0,1413}{0,8626-0,1413}\right] * 0,5+\left[\frac{0,1710-0,0462}{0,30-0,0462}\right] *(1-0,5) \\
& =\left[\frac{0,3547}{0,7213}\right] * 0,5+\left[\frac{0,126}{0,335}\right] *(0,5) \\
& =(0,4918 * 0,5)+(03761, * 0,5) \\
& =0,2459+0,1805=0,4339 \\
& \mathrm{Q}(\mathbf{A 1 0})=\left[\frac{0,4989-0,1413}{0,8626-0,1413}\right] * 0,5+\left[\frac{0,15-0,0462}{0,30-0,0462}\right] *(1-0,5) \\
& =\left[\frac{0,3576}{0,7213}\right] * 0,5+\left[\frac{0,105}{0,335}\right] *(0,5) \\
& =(0,4958 * 0,5)+(0,3134 * 0,5) \\
& =0,2479+0,1567=0,4046 \\
& =(0,6509 * 0,5)+(1 * 0) \\
& =0,3255+0,5=0,8255
\end{aligned}
$$

$\mathrm{Q}(\mathbf{A} 12)=\left[\frac{0,4542-0,1413}{0,8626-0,1413}\right] * 0,5+\left[\frac{0,1842-0,0462}{0,30-0,0462}\right] *(1-0,5)$ 


$$
\begin{aligned}
& =\left[\frac{0,3129}{0,7213}\right] * 0,5+\left[\frac{0,1392}{0,335}\right] *(0,5) \\
& =(0,4338 * 0,5)+(0,4155 * 0,5) \\
& =0,2169+0,2078=0,4247 \\
\mathrm{Q}(\mathbf{A 1 3}) & =\left[\frac{0,51-0,1413}{0,8626-0,1413}\right] * 0,5+\left[\frac{0,3-0,0462}{0,30-0,0462}\right] *(1-0,5) \\
& =\left[\frac{0,3687}{0,7213}\right] * 0,5+\left[\frac{0,255}{0,335}\right] *(0,5) \\
& =(0,5112 * 0,5)+(0,7612 * 0,5) \\
& =0,2556+0,3806=0,6362 \\
\mathrm{Q}(\mathbf{A 1 4}) & =\left[\frac{0,8626-0,1413}{0,8626-0,1413}\right] * 0,5+\left[\frac{0,1-0,0462}{0,30-0,0462}\right] *(1-0,5) \\
& =\left[\frac{0,7212}{0,7213}\right] * 0,5+\left[\frac{0,055}{0,335}\right] *(0,5) \\
& =(1 * 0,5)+(0,1642 * 0,5) \\
& =0,5+0,0821=0, \\
\mathrm{Q}(\mathbf{A 1 5}) & =\left[\frac{0,7074-0,1413}{0,8626-0,1413}\right] * 0,5+\left[\frac{0,2-0,0462}{0,30-0,0462}\right] *(1-0,5) \\
& =\left[\frac{0,5661}{0,7213}\right] * 0,5+\left[\frac{0,115}{0,335}\right] *(0,5) \\
& =(0,7848 * 0,5)+(0,4627 * 0,5) \\
& =0,3924+0,231=0,6234
\end{aligned}
$$

\subsection{Hasil Metode VIKOR}

Dari perhitungan indeks Vikor (Q) diatas maka diperoleh tabel peringkat indeks Vikor.

Tabel 6. Indeks Vikor

\begin{tabular}{|c|c|c|}
\hline Alternatif & Nilai Q & Peringkat \\
\hline A5 & 0 & 1 \\
\hline A3 & 0,3671 & 2 \\
\hline A10 & 0,4046 & 3 \\
\hline A8 & 0,4114 & 4 \\
\hline A12 & 0,4247 & 5 \\
\hline A9 & 0,4339 & 6 \\
\hline A6 & 0,4567 & 7 \\
\hline A4 & 0,4848 & 8 \\
\hline A14 & 0,5821 & 9 \\
\hline A7 & 0,589 & 10 \\
\hline
\end{tabular}

Dari tabel diatas diperoleh data bahwa alternatif (A5, A3, A10, A8, A12, A9, A6, A4, A14, A7) yaitu Eka Maya Sari, Desi Indriyani, Muhammad Syahri, Indah Utari, Putri Seruni, Mahmuda Ramadhan, Fitriyani, Eka Julisma Nst, Rolies Naibaho, Halimatus Sakdiah yang memiliki nilai indeks Vikor terkecil yaitu $((\mathbf{0}),(\mathbf{0 , 3 6 7 1}),(\mathbf{0 , 4 0 4 6}),(\mathbf{0 , 4 1 1 4}),(\mathbf{0 , 4 2 4 7})$ $(\mathbf{0 , 4 3 3 9}),(\mathbf{0 , 4 5 6 7}),(\mathbf{0 , 4 8 4 8}),(\mathbf{0 , 5 8 2 1}),(\mathbf{0 , 5 8 9}))$, sehingga dalam penelitian ini mereka lolos dalam penyelesian metode vikor dan terpilih sebagai colour guard dan menjadi anggota pada marching band GINADA.

\subsection{Penerapan Metode BORDA}

Perhitungan metode borda untuk menentukan keputusan penyeleksian colour guard adalah sebagai berikut;

a. Dari hasil perhitungan referensi dari masing-masing pengambil keputusan, hitung jumlah nilai referensi yang menyatakan rangking untuk tiap alternative. Tuliskan angka nilai preferensinya pada kolom satu untuk peringkat 1 , dua untuk peringkat 2 , dan seterusnnya

b. Kalikan angka pada kolom peringkat dengan bobot dibawahnya kemudian tambahkan dengan hasil perkalian pada jenis yang sama kemudian isikan hasil pada kolom rangking.

c. Jumlah hasil rangking, sehingga membentuk poin borda.

d. Untuk mencari nilai borda, bagi poin borda tiap alternative dengan jumlah poin borda.

Tabel 7. Pemilihan

\begin{tabular}{|l|l|l|l|l|l|l|l|l|l|l|}
\hline Alternatif & A5 & A3 & A10 & A8 & A12 & A9 & A6 & A4 & A14 & A7 \\
\hline Pelatih 1 & 1 & 1 & 4 & 4 & 2 & 1 & 3 & 2 & 3 & 1 \\
\hline Pelatih 2 & 2 & 1 & 2 & 4 & 5 & 5 & 3 & 2 & 5 & 2 \\
\hline
\end{tabular}




\begin{tabular}{|l|l|l|l|l|l|l|l|l|l|l|}
\hline Pelatih 3 & 3 & 2 & 5 & 1 & 5 & 1 & 1 & 3 & 4 & 3 \\
\hline Guru & 3 & 2 & 1 & 2 & 4 & 4 & 2 & 5 & 4 & 4 \\
\hline Senior & 5 & 3 & 1 & 3 & 1 & 4 & 2 & 5 & 2 & 5 \\
\hline
\end{tabular}

Tabel 8. Bobot Rangking Borda

\begin{tabular}{|c|c|}
\hline Rangking & Bobot \\
\hline 1 & 0.30 \\
\hline 2 & 0.25 \\
\hline 3 & 0.20 \\
\hline 4 & 0.15 \\
\hline 5 & 0.10 \\
\hline
\end{tabular}

Tabel 9. Perhitungan Borda

\begin{tabular}{|c|c|c|c|c|c|c|c|}
\hline \multirow[t]{2}{*}{ Alternatif } & \multicolumn{5}{|c|}{ Peringkat } & \multirow[t]{2}{*}{ Poit Borda } & \multirow[t]{2}{*}{ Ranking } \\
\hline & 1 & 2 & 3 & 4 & 5 & & \\
\hline A5 & 1 & 1 & 2 & - & 1 & 1,05 & 4 \\
\hline A3 & 2 & 2 & 1 & - & - & 1,3 & 1 \\
\hline A10 & 2 & 1 & - & 1 & 1 & 1,1 & 3 \\
\hline A8 & 1 & 1 & 1 & 2 & - & 1,05 & 5 \\
\hline A12 & 1 & 1 & - & 1 & 2 & 0,9 & 8 \\
\hline A9 & 2 & - & - & 2 & 1 & 1 & 7 \\
\hline A6 & 1 & 2 & 2 & - & - & 1,2 & 2 \\
\hline$\overline{\mathbf{A 4}}$ & - & 2 & 1 & - & 2 & 0,9 & 9 \\
\hline A14 & - & 1 & 1 & 2 & 1 & 0,85 & 10 \\
\hline A7 & 2 & - & 1 & 1 & 1 & 1,05 & 6 \\
\hline $\begin{array}{l}\text { Bobot } \\
\text { Ranking }\end{array}$ & $\mathbf{0 , 3 0}$ & 0,25 & $\mathbf{0 , 2 0}$ & $\mathbf{0 , 1 5}$ & $\mathbf{0 , 1 0}$ & 10,4 & \\
\hline
\end{tabular}

\subsection{Hasil Metode BORDA}

Berdasarkan hasil pada table 9., maka didapatkan urutan rekomendasi alternatif keputusan kelompok pengambilan keputusan yaitu $1=\mathrm{A} 3 ; 2=\mathrm{A} 6 ; 3 \mathrm{~A} 10 ; 4=\mathrm{A} 5 ; 5=\mathrm{A} 8$. Hasil dari perhitungan borda merupakan rekomendasi keputusan kelompok. Berdasarkan 10 rekomendasi alternatif, maka akan diambil 5 anggota colour guard yang akan mengikuti event.

Tabel 10. Perhitungan Hasil Borda

\begin{tabular}{|c|c|c|}
\hline Alternatif & Hasil Borda & Peringkat \\
\hline A3 & 1,3 & 1 \\
\hline A6 & 1,2 & 2 \\
\hline A10 & 1,1 & 3 \\
\hline A5 & 1,05 & 4 \\
\hline A18 & 1,05 & 5 \\
\hline
\end{tabular}

\section{KESIMPULAN}

Berdasarkan dari hasil penelitian yang penulis lakukan mengenai penyeleksian colour guard pada marching band GINADA dengan menggunakan metode VIKOR dan Borda untuk suatu sistem pendukung keputusan penyeleksian anggota penulis menarik kesimpulan penyeleksian menggunakan dua tahap yaitu; tahap awal penyeleksian menggunakan metode Vikor dalam penyeleksian calon colour guard menjadi anggota, kemudian tahap kedua penyeleksian dari anggota menjadi peserta colour guard untuk tiap event dengan metode Borda. Pada pengimplementasianya metode VIKOR dan metode Borda dilakukan perhitungan terhadap masin-masing kriteria sehingga diperoleh hasil yang akurat dan dapat diterapkan dengan sangat baik khususnya pada penyeleksian colour guard. 


\section{DAFTAR PUSTAKA}

[1] K. Konsep dan Aplikasi Sistem Pendukung Sitem, Yogy akarta, ANDI, 2007

[2] Penerapan Metode VIKOR pada Pengambilan Keputusan Seleksi Calon Penerima Beasiswa Bidikmisi Universitas Terbuka: Denpasar, Gede Suwardika, 2018

[3] IMPLEMENTASI ANALITICAL HIERARCHY PROCESS (AHP)-TOPSIS DAN BORDA PEMILIHAN TANAMAN OBAT UNTUK PENYAKIT BATUK: Kalimantan selatan Ismail Prasetia, 2017

[4] K. Konsep dan Aplikasi Sistem Pendukung Sitem, Yogy akarta: ANDI, 2017.

[5] B. S. D. Oetomo, Perencanaan dan Pembangunan Sistem Informasi, Yogy akarta: ANDI, 2016.

[6] Kusrini, konsep dan aplikasi Pendukung Keputusan, Yogy akarta: CV ANDI, 2007.

[7] I ketua putut suniaantara Gede Suwaardika, "penerapan metode vikor pada pengambilan keputusan seleksi calon penerima beasiswa bidikmisi universitas terbuka, “ INTENSIF., p, 24, 1 February 2018

[8] D. Nofriansy ah, Multi Criteria Decision Making,Yogy akarta:Deepublish,2017

[9] R. P. Sari, A. J. Santoso dan E. , "PERANCANGAN SISTEM PENDUKUNG KEPUTUSAN KELOMPOK METODE TOPSIS DAN BORDA UNTUK EVALUASI KEGIATAN PENANGANANINFRASTRUKTUR JALAN,” Seminar Nasional Teknologi Informasi dan Komunikas, pp. 321-329, 2014

[10] B. Kho, "Ilmu Manajemen Indrustri," 26 April 2017. [Online]. Available: https://ilmumanajemenindustri.com/pengertian-seleksiproses-seleksi-penerimaan-kary awan/.

[11] C. Wuditha, "MarchingGeek.Com,” 05 Desember 2015. [Online]. Available: http://marchinggeek.com/peran-divisi-colour-guarddalam-marching-band/.

[12] H. Jogiy anto, Sistem Teknologi Informasi, Yogy akarta: ANDI, 2013.

[13] Pemograman Visual Basic Primananda Arif Aditya, 2013

[14] Rosa, A.S. and Shalahuddin, M., Rekay asa Perangkat Lunak Terstruktur dan Berorientasi Objek, 2013, Bandung, Informatika Bandung

[15] INFORMATIKA, Menggunakan UML, Widodo, Prabowo Pudjo and Herlawati, Bandung, 2011

[16] Sistem Informasi Perpustakaan Online Berbasis Web Astria Firman, Hans F. Wowor, Xaverius Najoan, 2016

[17] F. Pratiwi, F. T. Waruwu, D. P. Utomo and R. Sy ahputra, "Penerapan Metode Aras Dalam Pemilihan Asisten Perkebunan Terbaik Pada PTPN V," Seminar Nasional Teknologi Komputer \& Sains (SAINTEKS), vol. 1, no. 1, pp. 651-662, 2019.

[18] S. W. Pasribu, D. P. Utomo and M. Mesran, "Sistem Pendukung Keputusan Penerimaan Account Officer Menerapkan Metode EXPROM II (Studi Kasus: Bank Sumut)," Journal of Information System Research (JOSH, vol. 1, no. 3, pp. 175-188, 2020.

[19] Mesran, K. Ulfa, D. P. Utomo and I. R. Nasution, "Penerapan Metode VlseKriterijumska Optimizacija I Kompromisno Resenje (VIKOR) dalam Pemilihan Air Conditioner Terbaik," LGORITM A: JURNAL ILMU KOMPUTER DAN INFORMATIKA, vol. 4, no. 1, pp. 24-35, 2020.

[20] M. Mesran, S. Suginam and D. P. Utomo, "Implementation of AHP and WASPAS (Weighted Aggregated Sum Product Assessment) Methods in Ranking Teacher Performance," IJISTECH (International Journal of Information Sy stem \& Technology), vol. 3, no. 2, pp. 173-182, 2020. 